\title{
Development of Learning Materials with Socratic Model at History of Physics *)
}

\author{
Nadi Suprapto ${ }^{* *}$ \& Dwikoranto \\ Email: nadi_unesa@yahoo.co.id \\ *) The result of "Hibah Bersaing" Research 2009 \\ ${ }^{* *}$ Department of Physics, Surabaya State University
}

\begin{abstract}
:
A history of physics lecture become important for the student because its knowledge will be a complement as knowledge framework from all that have and will be obtained by students. This is an optional lecture for the student of physics education by 2 credit which is programmed at even semester. Though an optional lecture, this is still very enthused by students. Pursuant to this situation hence done a research and development (R and D) to this lecture. Research done by student of Reguler Physics Education 2006. The aim of this research is to develop learning materials include Lesson Plan (GBRP and SAP), dictate, Student Worksheet ( $L K M)$, Appraisal Sheet $(L P)$, hands out, physician pictures and poster oriented to socratic model. Then those are tried to the student. The result shows the ability of lecturer in managing study of Socrates categorize goodness. Result of management at introduction and activity of class condition shows that the category is very good, while for core activities, closure, and time management shows good enough category, from perception mean score $\geq 3.0$ every study steps. Student activity cover: listening actively, reading, doing and writing answer in $L K M$, discussing with lecturer, discussing between student in group, making resume, and irrelevant behavior successively are $14.50 \%, 13.50 \%, 16.50 \%, 27.75 \%$, $20.75 \%, 7.00 \%$ and $0.00 \%$. The biggest percentage activity is to discuss with lecturer, while smallest activity percentage is to make resume and irrelevant behavior. Enthusiasm learn student at negative and positive statement criterion, mean score to every condition of attention, relevansion, confidence, and satisfaction (ARCS) successively is 4.00, 4.05, 4.15, and 3.45 with good category with mean score for all condition are 3.91 so that student enthusiasm criterion in good category. The learning product of pretest at learning show all product indicator is not complete with complete mean $27.68 \%$. Then after given by post test its result show complete mean equal to $81.67 \%$ and all item test is completed.
\end{abstract}

Key words: Development materials learning, Socratic Model, $R \& D$, History of Physics 


\section{Pendahuluan}

Berdasarkan kurikulum Fisika FMIPA UNESA, mata kuliah sejarah fisika merupakan mata kuliah pilihan bagi mahasiswa prodi pendidikan fisika dengan bobot 2 SKS yang diprogramkan pada semester genap dan tidak ada persyaratan khusus untuk memprogram mata kuliah ini. Sehingga pada tahun perkuliahan
2009/2010 pelaksanaan perkuliahan baru akan berjalan pada bulan Februari sampai Juni 2010. Meskipun berstatus mata kuliah pilihan namun mata kuliah ini amat diminati oleh mahasiswa. Tabel 1 menggambarkan distribusi minat mahasiswa terhadap mata kuliah ini dalam kurun waktu 3 tahun terakhir.

Tabel 1. Peserta Mata kuliah Sejarah Fisika untuk tiga tahun terakhir

\begin{tabular}{|c|c|c|c|c|c|c|}
\hline \multirow{2}{*}{ Kelas } & \multicolumn{2}{|c|}{$2006 / 2007$} & \multicolumn{2}{c|}{$2007 / 2008$} & \multicolumn{2}{c|}{$2008 / 2009$} \\
\cline { 2 - 7 } & $\begin{array}{c}\text { Jumlah } \\
\text { Mahasiswa }\end{array}$ & $\begin{array}{c}\text { Jumlah } \\
\text { Peminat }\end{array}$ & $\begin{array}{c}\text { Jumlah } \\
\text { Mahasiswa }\end{array}$ & $\begin{array}{c}\text { Jumlah } \\
\text { Peminat }\end{array}$ & $\begin{array}{c}\text { Jumlah } \\
\text { Mahasiswa }\end{array}$ & $\begin{array}{c}\text { Jumlah } \\
\text { Peminat }\end{array}$ \\
\hline PF04R & 54 & 51 & - & - & - & - \\
\hline PF04NRA & 38 & 30 & - & - & - & - \\
\hline PF04NRB & 33 & 25 & - & - & - & - \\
\hline PF05R & - & - & 53 & 48 & - & - \\
\hline PF05NR & - & - & 40 & 28 & - & - \\
\hline PF06 R & - & - & - & - & 28 & 26 \\
\hline PF06NR & - & - & - & - & 27 & 24 \\
\hline
\end{tabular}

(Sumber: Jurusan Fisika UNESA)

Melihat tren minat mahasiswa yang tinggi pada 3 tahun terakhir terhadap mata kuliah ini tentunya harus dibarengi oleh manajemen perkuliahan yang baik. Salah satu cara yang ditempuh peneliti sekaligus sebagai pengajar mata kuliah adalah mendesain perkuliahan yang menarik dan menjadi tambah diminati mulai dari persiapan, pelaksanaan, sampai pada evaluasi perkuliahan baik dari sisi proses maupun produknya.

Ketiga tahap tersebut sementara ini sudah dilakukan namun belum optimal, belum dikembangkan paket bahan pembelajaran yang utuh dan terintegrasi. Perkuliahan belum menerapkan modelmodel pembelajaran yang dapat meningkatkan aktivitas, antusiasme baik dosen maupun mahasiswa. Serta belum dilakukan evaluasi dan efektivitas pelaksanaan perkuliahan.

Perkuliahan menuntut mahasiswa berfikir kritis dan dialektik agar kegiatan belajar mengajar (KBM) berjalan dengan baik. Dosen perlu menggunakan model pembelajaran yang memacu pemikiran kritis dan dialektik mahasiswa. Salah satunya dengan menggunakan model Socrates dalam pembelajaran. Model yang dimaksud disini untuk selanjutnya sama dengan model yang mengalami pengembangan yang diwujudkan dalam bentuk tahapan/ sintaks selanjutnya akan digunakan kedua istilah yang disesuaikan konteksnya. Model Sokrates sebenarnya terlalu tua untuk diangkat kembali ke permukaan dalam bidang pendidikan, tetapi ke-tua-an model itu menjadikannya bertambah lebih memiliki nilai yang tidak ada bandingnya yaitu: dalam hal originalitas atau keasliannya.

Berdasarkan hasil penelitian terdahulu yang telah dilakukan Atmah (2004) yang menerapkan bentuk pembelajaran bertanya dengan Pola Pembelajaran Melalui Pertanyaan (PBMP) yang dikembangkan, efektif untuk mencapai tujuan yang diharapkan, dengan hasil keterlaksanaan pembelajaran $100 \%$ berkategori baik, persentase aktivitas siswa tinggi, dalam mengemukakan ide sebesar $5.18 \%$, menanggapi pendapat orang lain 
$33.43 \%$, mengajukan pertanyaan $7.97 \%$, menjawab pertanyaan $42.15 \%$ dan perilaku yang tidak relevan $1.27 \%$, kemampuan penalaran siswa cukup baik, minat dan motivasi siswa dalam kategori baik, hasil belajar siswa tuntas secara klasikal sebesar 91.67\%, sedangkan penelitian lain yang dilakukan oleh Murtafiah (2004) yang mengembangkan pembelajaran bertanya (sebagai inti dari model Socrates) yang disesuaikan dengan taksonomi bertanya Bloom, telah menunjukkan bahwa pembelajaran berlangsung efektif dan keterampilan berpikir siswa dapat dilatih dengan menggunakan taksonomi bertanya, dengan hasil penelitian untuk hasil belajar siswa tuntas dengan nilai $\geq 65$ sebanyak $80 \%$, kemampuan guru mengelola pembelajaran berkategori baik, interaksi siswa guru tinggi dalam merespon percakapan, yang mengindikasikan bahwa siswa aktif dalam membangun pemahaman mereka sendiri dalam pembelajaran.

Salah satu yang menarik bagi Peneliti adalah ingin mengembangkan bentuk pembelajaran bertanya lainnya yaitu pembelajaran model Sokrates, yang akan terapkan dalam rangka perkuliahan Sejarah Fisika pada materi sejarah atom.

Model Sokrates adalah model pembelajaran bertanya-jawab dilakukan oleh Sokrates. Model ini merupakan metode awal pembelajaran kuno yang masih asli, dan keberadaannya sampai sekarang adalah sebagai kerangka awal dari terbentuknya model-model pembelajaran baru yang telah mapan saat ini, misalnya: Model PBI dari ciri berpikiris kritis, Model Diskusi dari sisi teknik, Model kooperatif dari ciri kerja sama atau kooperasi menghargai pendapat orang lain dalam berdialektika.

Jadi dalam penelitian ini, peneliti mencoba untuk memenuhi harapanharapan yang telah diuraikan di atas, dengan pengembangan perangkat model Sokrates yang dihasilkan dan implementasi dalam pembelajaran dapat mencapai ketuntasan hasil belajar mahasiswa secara optimal dan tingkat pemahaman yang lebih.

Berdasarkan uraian tersebut perlu dikembangkan paket bahan pembelajaran yang utuh dan terintegrasi mata kuliah sejarah fisika untuk diterapkan pada perkuliahan dan selanjutnya diterapkan dalam skala yang lebih luas. Setelah paket bahan pembelajaran dikembangkan oleh peneliti, akan diujicobakan secara terbatas kepada mahasiswa sebelum digunakan dalam pembelajaran pada tahun berikutnya.

Rumusan masalah dalam penelitian ini adalah Bagaimanakah bahan pembelajaran model Socrates (GBRP, SAP, diktat perkuliahan, hands out, LKM, lembar penilaian, dan poster) yang dikembangkan peneliti untuk mata kuliah sejarah fisika. Selanjutnya selama penerapan perangkat pembelajaran (uji coba terbatas) ingin diketahui hal-hal sebagai berikut:

a. Bagaimanakah pengelolaan pembelajaran sejarah fisika dengan model Socrates?

b. Bagaimanakah aktivitas mahasiswa pada pembelajaran sejarah fisika dengan model Socrates?

c. Bagaimanakah minat mahasiswa terhadap pembelajaran sejarah fisika dengan menerapkan model Socrates?

d. Bagaimanakah ketuntasan hasil belajar sejarah fisika dengan menerapkan model Socrate

\section{Metode Penelitian}

Penelitian ini merupakan penelitian pengembangan (Research and Development). Peneliti mengem-bangkan bahan pembelajaran mata kuliah sejarah fisika selanjutnya diimplementasikan di kelas dan diteliti variabel-variabel yang berhubungan dengan peningkatan kualitas pembelajaran. Dalam pelaksanaanya pendekatan kuantitatif digunakan untuk mendeskripsikan keterlaksanaan model Socrates yang diterapkan, pengelolaan pembelajaran, aktivitas mahasiswa dalam pembelajaran, minat mahasiswa, 
memperoleh informasi peningkatan hasil belajar mahasiswa, serta kelayakan bahan pembelajaran. Data-data di atas dianalisis menggunakan deskriptif kuantitatif dengan persentase.

Subjek penelitian adalah mahasiswa pemrogram matakuliah sejarah físika jurusan fisika FMIPA Unesa angkatan tahun 2006 dengan jumlah 10 mahasiswa.

Prosedur penelitian mengacu pada pengembangan perangkat pembelajaran model 4D (four D model) (Thiagarajan, S., Semmel, D. \& Semmel, M.I. , 1974) yang dimodifikasi dan disesuaikan dengan kebutuhan.

\section{Hasil Penelitian dan Pembahasan}

\subsection{Hasil Pengembangan Perangkat Pembelajaran}

Hasil pengembangan perangkat yang diorientasikan pada pembelajaran model Sokrates untuk materi sejarah atom, telah dihasilkan beberapa perangkat pembelajaran yang terdiri dari Garis-garis Besar Rencana Perkuliahan (GBRP), Satuan Acara Pembelajaran (SAP), Lembar Kegiatan Mahasiswa (LKM), Tes Hasil Belajar (THB), Diktat Mahasiswa, hands out, dan poster.

Pembahasan hasil penelitian pengembangan perangkat pembelajar-an didasarkan atas telaah para validator beserta perangkat pendukungnya. Berdasarkan telaah para validator diketahui secara umum perangkat pembelajaran yang dikembangkan telah layak dan dapat digunakan dengan perbaikan-perbaikan. Keadaan perangkat Draf I, setelah direvisi dengan didasarkan atas masukan-masukan para validator menghasilkan perangkat Draf II. Keadaannya secara umum seperti penulisan beberapa kata telah disesuaikan dengan ejaan yang berlaku dan penggantian soal tes dan gambar yang belum sesui dengan hasil belajar yang diharapkan. Selain dari telaah para validator, perbaikan-perbaikan perangkat juga didasarkan atas hasil seminar pembahsan proposal dan laporan kemajuan penelitian yang telah dilaksanakan, dan memperoleh masukan-masukan konstruktif dari para peserta seminar dan pembahas. Dari tahapan tersebut diketahui bahwa: hasil pengembangan perangkat pembelajaran Draft I belum mencerminkan usaha-usaha yang jelas dan terarah untuk mencapai tujuan pembelajaran/indikator yang ditetapkan, sehingga sifat perangkat yang dihasilkan masih umum dan tidak fokus. Oleh karena itu yang disarankan oleh pembahas adalah dalam pengembangan perangkat pembelajaran harus benar-benar diorientasikan pada usaha-usaha pada bagaimana dapat tercapainya tujuan pembelajaran /indikator yang ditetapkan.

Dari hasil validasi para validator dan masukan pembahas serta para peserta seminar proposal, oleh peneliti segera ditindak lanjuti dengan melakukan perbaikan perangkat Draf I. Hasil revisi ke-1 yang telah dilakukan menghasilkan Draf II sebelum digunakan dalam penelitian Uji Coba I (uji coba terbatas). Dari hasil penelitian Uji Coba I, peneliti mendapatkan masukan konstruktif dari para pengamat dan data lapangan yang digunakan sebagai dasar perbaikan pada revisi ke-2 menghasilkan perangkat Draf III sekaligus melanjutkan penelitian tahun kedua.

Dari proses pengembangan perangkat yang direncanakan dan yang telah dilakukan di atas, maka semua perangkat yang dikembangkan itu berorientasi pada pembelajaran model Sokrates sesuai dengan karakteristik materi sejarah atom. Pada proses pengembangan perangkat, dapat diketahui bahwa: perangkat pembelajaran yang dikembangkan peneliti telah layak untuk digunakan dalam kegiatan belajar mengajar utuh sejarah fisika semester genap 2009/2010, untuk Mahasiswa Jurusan Fisika FMIPA Unesa. 


\subsection{Pembahasan Hasil Implementasi Perangkat Pembelajaran Implementasi perangkat pembelajaran termasuk dalam rangkaian proses pengembangan perangkat} pembelajaran, yaitu tahap pengembangan (develop). Tujuan pengembangan tersebut adalah untuk mengetahui efektivitas pembelajaran menggunakan perangkat pembelajaran yang dikembangkan, sekaligus menentukan keberhasilan dalam pencapaian ketuntasan hasil belajar mahasiswa, maka pembelajaran menggunakan perangkat pembelajaran dengan menerapkan model Sokrates yang dikembangkan ini dilihat dari kemampuan pengelolaan pembelajaran, aktivitas mahasiswa, minat dan motivasi mahasiswa terhadap pembelajaran, dan hasil belajar mahasiswa, yang disampaikan sebagai berikut.

\subsection{Kemampuan pengajar dalam mengelola pembelajaran}

Hasil analisis kemampuan pengajar untuk tiap-tiap aspek dalam mengelola pembelajaran pada Uji Coba I menunjukkan hasil dengan kategori cukup baik dan sangat baik. Dari 5 aspek yang diamati, yaitu pendahuluan, kegiatan inti, penutup, pengelolaan waktu dalam PBM dan suasana kelas, menunjukkan bahwa semua aspek tersebut dapat terlaksana.

Keberhasilan pengajar dalam mengelola KBM yang berorientasi pada model Sokrates harus ditunjang dengan perangkat pembelajaran yang diorganisasikan secara baik. Dengan perangkat yang baik dapat memperlancar jalannya pengelolaan pembelajaran, misalnya pada Satuan Acara Perkuliahan (SAP) yang dikembangkan harus dilengkapi dengan langkah-langkah yang cukup rinci, bagaimana memotivasi mahasiswa, sampai pada bagaimana penilaian yang sesuai untuk dilaksanakan dalam pembelajaran tersebut. Selain SAP, untuk perangkat LKM yang berorientasi pada model Sokrates, seharusnya dikembangkan untuk dapat memberikan kesempatan kepada mahasiswa mengembangkan pola pikir kritis dari rangkaian pertanyaan yang diajukan, sehingga didapatkan perolehan pengertian dan pemahaman secara maksimal. Untuk perangkat diktat mahasiswa sangat menunjang sekali kelancaran pembelajaran, yang oleh mahasiswa digunakan untuk mendapatkan informasiinformasi secara mandiri dalam rangka mengerjakan tugas-tugas yang ada di dalam LKM dan evaluasi tes formatif yang diajukan. Sedangkan untuk perangkat evaluasi akhir diberikan Tes Hasil Belajar (THB), yang diberikan secara terpisah dari kegiatan belajar mengajar pada pertemuan berikutnya. THB tersebut harus dikembangkan dalam rangka untuk dapat mengukur kompetensi tertentu, yang diharapkan dalam pembelajaran sesuai dengan indikator yang telah ditetapkan.

\subsection{Aktivitas mahasiswa dalam kegiatan belajar mengajar}

Berdasarkan analisa data tampak bahwa implementasi perangkat untuk SAP, LKM dan diktat mahasiswa mampu mengaktifkan mahasiswa dalam mengungkapkan ide, mengajukan pertanyaan lanjutan dan menuntut klarifikasi. Dengan demikian dalam kegiatan pembelajaran, yang dilaksanakan sesuai dengan langkahlangkah model Sokrates, sehingga metode tersebut dapat membantu mahasiswa terlibat secara aktif dalam menemukan konsep-konsep yang baru bagi dirinya.

Sesuai dengan ciri khas yang ada dalam pembelajaran Sokratik, selain mahasiswa yang aktif dalam mengkonstruk pengetahuan dalam dirinya, maka peran pengajar sangat penting (vital) dalam memberikan arah/jalan bagaimana suatu konsep harus ditemukan, melalui sebuah wahana diskusi. Data di atas didukung oleh teori yang mengatakan bahwa: perkembangan kognitif sebagian besar ditentukan oleh interaksi aktif pebelajar dengan lingkungan dan interaksi sosial dengan teman sebaya, khususnya dalam berargumentasi dan berdiskusi 
dapat membantu memperjelas pemikiran yang pada akhirnya memuat pemikiran menjadi logis (Nur, 1998).

Tingginya persentase frekuensi aktivitas mahasiswa berdiskusi dengan pengajar dan berdiskusi antara sesama mahasiswa dalam kelompok, maka berdasarkan data di atas, menunjukkan bahwa hasil penelitian tersebut relevan dengan teori yang melandasi pelaksanaan pembelajaran Sokratik. Teori perkembangan Piaget memandang perkembangan kognitif sebagai suatu proses dimana pebelajar secara aktif membangun sistem makna dan pemahaman realitas lingkungan melalui pengalaman dan interaksi mereka. Menurut Piaget perkembangan kognitif sebagian besar tergantung pada seberapa jauh pebelajar aktif memanipulasi dan aktif berinteraksi dengan lingkungan.

Berdasarkan kategori yang diamati selama kegiatan pembelajaran menunjukkan bahwa aktivitas pembelajaran mahasiswa akan baik, jika langkah-langkah pembelajaran model Sokrates yang diuraikan dalam Satuan Acara Perkuliahan dapat terlaksana dengan baik juga. Jadi secara keseluruhan implementasi perangkat yang dikembangkan ini mampu mengaktifkan mahasiswa dalam kegiatan belajar mengajar.

\subsection{Minat mahasiswa}

Di tinjau keseluruhan skor minat pada Uji Coba I, dengan melihat skor ratarata semuanya di atas 3 mendekati angka 4 , berarti rata-rata mahasiswa menyatakan setuju untuk pernyataan berkriteria positif dan tidak setuju untuk penyataan berkriteria negatif, sehingga dapat dikatakan bahwa mahasiswa mempunyai minat yang baik terhadap pembelajaran. Minat yang baik dapat pula dilihat pada saat pembelajaran; yaitu baik perhatian, relevasi, percaya diri dan kepuasan mahasiswa, dapat dilihat dari keaktifan mengikuti perkuliahan, kemampuan dalam mengaitkan pembelajaran dengan lingkungan dan kehidupan sehari-hari; dari keantusiasan mahasiswa untuk berpartisipasi dalam diskusi; dan dari suasana saat pembelajaran berlangsung yang terlihat menyenangkan.

Menurut Kardi (2002 b), empat kondisi minat mahasiswa yaitu perhatian (Attention), relevansi (Relevance), percaya diri (Confidence), dan kepuasan (Satisfaction) harus dipenuhi agar manusia menjadi tetap berminat dan termotivasi. Berdasarkan hasil analisis kedua hasil angket tersebut, dapat dikatakan bahwa pada pembelajaran menggunakan perangkat pembelajaran dengan menerapkan model Sokrates yang dikembangkan dapat memenuhi keempat kondisi agar mahasiswa tetap mempunyai minat terhadap pembelajaran dan motivasi terhadap materi perkuliahan yang baik.

Dari Uraian di atas dapat diringkas bahwa minat mahasiswa terhadap pembelajaran dan materi perkuliahan yang diterapkan dan diorientasikan dengan model Sokrates, sangat mendukung kelancaran proses pembelajaran. Perhatian mahasiswa terhadap pembelajaran juga baik, karena mahasiswa merasakan sebuah tantangan untuk memecahkan konflik kognitif yang dianggap menarik dapat memicu hal baru dalam penyajian perkuliahan serta keikutsertaan proses kinerja mental. Mahasiswa juga menganggap pembelajaran relevan dengan keperluan mereka, karena pada bagian lembar tanya jawab terstrutur di dalam LKM terdapat tugas-tugas untuk mengamati gambar-gambar kongkrit, atau analogi fakta dan data-data yang terkait langsung dengan objek persoalan yang dikaji dalam pembelajaran, yang masih memiliki keterkaitan dengan keperluan mereka. Sikap percaya diri mahasiswa terhadap keberhasilan pembelajaran mereka baik, yang dapat dilihat dari keaktifan mereka dalam melaksanakan tugas dalam lembar kegiatan mahasiswa (LKM) dan diskusi. Mahasiswa juga merasa puas karena dalam pembelajaran setiap upaya yang dilakukan mahasiswa 
selalu diberikan apresiasi/penghargaan yang dianggap sesuai.

\subsection{Hasil belajar mahasiswa}

Berdasarkan analisis deskriptif hasil belajar, pada Uji Coba I diperoleh hasil-hasil sebagai berikut. Uji awal menunjukkan semua indikator butir soal pada Uji Coba I tidak tuntas dengan ratarata $27.68 \%$, dan uji akhir menunjukkan rata-rata ketuntasan indikator butir soal tuntas dengan rata-rata sebesar $81.67 \%$. Proporsi indikator produk pada Uji Coba I yang diperoleh kisaran nilai terrendah antara $69.44 \%$ sampai dengan tertinggi sebesar $95.83 \%$ dengan rata-rata $81.67 \%$. Indeks sensitivitas butir soal rata-rata pada Uji Coba I: 0.54, maka dapat dilihat semua sensitivitas butir soal hampir di atas 0.50 berarti semua soal sensitif. Berarti butir soal yang digunakan dapat mengukur efek pembelajaran Sokrates untuk materi sejarah atom. Menurut Aiken dalam Hoetawarman (2001), butir soal yang mempunyai sensitivitas $\geq 0,30$ telah dapat disebut peka terhadap efekefek pembelajaran atau sensitif.

Berdasarkan hasil analisis deskriptif tes hasil belajar mahasiswa di atas, pada Uji Coba I terjadi peningkatan proporsi ketuntasan rata-rata pada uji awal dari $28.16 \%$, pada uji akhir menjadi 81.64 $\%$. Ketuntasan individual maupun klasikal THB produk untuk uji akhir pada Uji Coba I dapat dicapai semua mahasiswa, artinya mahasiswa tuntas belajar. Disimpulkan baik secara individual dan klasikal ketuntasan hasil belajar mahasiswa pada Uji Coba I dapat tercapai. Dengan dasar ketuntatasan individual dan klasikal sebesar $56 \%$, berarti bahwa pembelajaran dengan menerapkan model Sokrates dapat menuntaskan hasil belajar mahasiswa.

Jadi secara keseluruhan dari data proporsi ketuntasan rata-rata tes hasil belajar pada Uji Coba I terdapat perbedaan yang menunjukkan kecenderungan meningkat baik pada uji awal (U-1) maupun uji akhir (U-2). Perbedaanperbedaan proporsi ketuntasan rata-rata tes hasil belajar mahasiswa tersebut, sejalan dengan pemahaman bahwa manusia diciptakan oleh Tuhan memiliki potensi dan keunikan tersendiri, jadi sangat jelas bahwa pengetahuan seseorang itu berbedabeda pula baik dalam keluasan maupun kedalamannya.

\section{Kesimpulan dan Rekomendasi}

Simpulan yang dapat ditarik dari penelitian ini adalah:

a. Bahan pembelajaran yang telah dikembangkan oleh peneliti meliputi Garis-garis Besar Rencana Perkuliahan (GBRP), Satuan Acara Perkuliahan (SAP), diktat perkuliahan, Lembar Kegiatan Mahasiswa (LKM), lembar penilaian (LP), hands out, foto fisikawan dan poster mata kuliah sejarah fisika yang berorientasikan pada model Socrates.

b. Kemampuan pengajar dalam mengelola pembelajaran Socrates berkategori baik. Hasil pengelolaan yang didapat pada kegiatan pendahuluan dan kondisi suasana kelas menujukkan kategori sangat baik, sedangkan untuk kegiatan inti, penutup dan pengelolaan waktu menunjukkan kategori cukup baik, dari skor rata-rata pengamatan $\geq 3.0$ tiap tahapan sintaks.

c. Aktivitas mahasiswa untuk masingmasing aktivitas meliputi: mendengarkan secara aktif, membaca buku ajar mahasiswa, mengerjakan dan menulis jawaban di LKM, berdiskusi dengan pengajar, berdiskusi antara sesama mahasiswa dalam kelompok, membuat rangkuman hasil pembelajaran dan perilaku yang tidak relevan berturut-turut adalah $14.50 \%$, $13.50 \%, 16.50 \%, 27.75 \%, 20.75 \%$, $7.00 \%$ dan $0.00 \%$. Persentase aktivitas terbesar adalah berdiskusi dengan pengajar, sedangkan persentase aktivitas terkecil adalah membuat rangkuman dan perilaku yang tidak relevan.

d. Minat belajar mahasiswa pada kriteria pernyataan positif dan negatif, skor 
rata-rata untuk tiap-tiap kondisi perhatian, relevansi, percaya diri dan kepuasan berturut-turut adalah 4.00, 4.05, 4.15, dan 3.45 dengan kategori baik, sedangkan skor rata-rata untuk semua kondisi adalah 3.91 dengan kriteria minat mahasiswa masuk dalam kategori baik.

e. Hasil belajar menunjukkan dari uji awal pada pembelajaran menunjukkan semua indikator produk tidak tuntas dengan rata-rata ketuntasan $27.68 \%$. Kemudian setelah uji akhir diberikan hasilnya menunjukkan rata-rata ketuntasan sebesar $81.67 \%$ dan semua butir soal tuntas.

Berdasarkan temuan dan kendala selama pelaksanaan penelitian, maka direkomendasikan beberapa hal:

a. Para pengajar dapat memilih model Socrates sebagai salah satu alternatif pembelajaran konstruktivis di kelas secara utuh untuk mata kuliah tertentu, mengingat penelitian ini sebatas pada satu topik saja: sejarah atom.

b. Perlu dilakukan penelitian tindak lanjut akan aktivitas afektif dan psikomotor apabila menggunakan model ini.

c. Kemampuan yang berhubungan dengan soft skill mahasiswa seyogianya juga diperhatikan pada model ini.

d. Pada pelaksanaan evaluasi akan lebih tepat jika assessment-nya menggunakan penilaian lisan, namun konsekuensinya pengalokasian waktu untuk setiap mahasiswa membutuhkan waktu yang banyak.

\section{Ucapan Terima Kasih}

Penelitian ini terselenggara atas bantuan Hibah melalui Penelitian Hibah Bersaing Tahun 2009. Untuk itu peneliti mengucapakan terima kasih kepada semua pihak, terutama Direktorat Penelitian dan Pengabdian kepada Masyarakat (DP2M) Dikti Depdiknas.

\section{Daftar Pustaka}

1) Atmah. 2004. "Pengembangan Perangkat pembelajaran Sains untuk SMP dan MTs Menerapkan Pola Pemberdayaan Berpikir Melalui Pertanyaan Pada sistem Ekskresi pada Manusia" Tesis, Magister Pendidikan Sains.. Tidak dipublikasikan. Surabaya. PPs Unesa.

2) Buku Pedoman Universitas Negeri Surabaya. TA. 2006, 2007,2008, 2009. Unesa.University Press. Surabaya.

3) Ennis, R. H. 1991. An Elaboration of a cardinal goal of science instruction, Educational philosophy and theory, 23(1), 31-43.

4) Johnson, David. W \& Johson, Robert, T. 2002. The Meaningful Assessing "A Manageable and Cooperative Process". Allyn and Bacon.

5) Kardi, S. 2002a. Mengembangkan Tes hasil Belajar. Surabaya: Universitas Negeri Surabaya.

6) Kardi, S. 2002b. Strategi Motivasi ARCS. Surabaya: Universitas Negeri Surabaya.

7) Murtafiah. R. 2004. “ Efektifitas Penggunaan Taksonomi Bertanya oleh Guru terhadap Keterampilan Berpikir Siswa SMP pada Pembelajaran Sains Materi Pokok Komponen Ekosistem, Peran dan Interaksinya. Tesis. Magister Pendidikan Sains. PPs UNESA.

8) Qosyim, A. 2007. Model Sokrates (Socrates Method). Studi Implikasi Model Socrates dalam Praktek Pendidikan. Surabaya: Pasca Sarjana UNESA.

9) Suprapto, N. \& Qosyim, A. 2007. "Penerapan Model Socrates (Socratic Method) untuk Menunjang Advance Organizer pada Perkuliahan Sejarah Fisika." Prosiding No ISBN 978-97917494-0-4. (Makalah yang dipresentasikan dalam Seminar Fisika UNAIR tanggal 4 September 2007 di Hotel Elmi Surabaya).

10) Suprapto, N \& Dwikoranto. 2009. "Pengembangan Bahan Pembelajaran (PBP) Model Socrates (Socratic 
Model) pada Perkuliahan Sejarah Fisika di Jurusan Fisika FMIPA UNESA". Laporan Penelitian Hibah Bersaing Tahun Pertama.

11) Thiagarajan, S., Semmel, D. \& Semmel, M.I. 1974. Instructional
Development for Training Teachers of Exeptional Children. Source Book Bloomington: Center for Innovation on Teaching the Handicapped. 